\title{
Zoning System In Education Application In The City Of Pasuruan, East Java
}

\section{Daryono}

Pendidikan Pancasila dan Kewarganegaraan, Fakultas Pedagogi dan Psikologi, Universitas PGRI Wiranegara Pasuruan, Jawa Timur, Indonesia daryono.jarwo@gmail.com

\section{Article History}

Received : December $13^{\text {th }} 2020$

Revision : February $27^{\text {th }} 2021$

Publication : March 30th 2021

\begin{abstract}
This paper examines the application of the zonation system in the City of Pasuruan. Based on preliminary observations of the zoning system in Pasuruan through the Education and Culture Office of Pasuruan City, it showed that; (a) the zoning system has been implemented in Pasuruan City, (b) there are written regulations regarding the implementation of zoning system policies in Pasuruan City, (c) there are technical guidelines regarding zoning system policies in Pasuruan City, (d) there is socialization regarding the requirements and flow of registration admission of new students (PPDB), (e) there is a schedule and time for registration, (f) there is a score for PPDB supporting values, (g) there is a school capacity, and (h) there is a division of zoning area designations. The purpose of this study was to explain parents' perceptions, equal access and improve the quality of education. The research method in this study used field research methods, namely direct observation of the research subject (parents of students) and combined with literature study. The research approach wass a qualitative approach. The qualitative research procedure produced descriptive data in the form of sentences or writings from other researchers as reinforcement of explanations in the articles and field data that the authors refer to. From the results of the study, most of the parents of students assumed that the zoning system policy was a process of admitting new students based on distance, namely the distance between the house to the school. The positive impact was that parents of students did not bother thinking children's transportation costs. The students' parents found that it was easier to monitor their children's interactions at school and in their neighborhood.
\end{abstract}

Keywords : Zoning System, Access and Quality Improvement, the City of Pasuruan.

\section{INTRODUCTION}

The zoning system in the context of education is an interesting issue to study. This is related to government policies, parents' perceptions, equal access and the improvement quality of education. The government policy regarding the zoning system is regulated by the Ministry of Education and Culture in Permendikbud Number 17 of 2017 which was then updated in 2018 in Permendikbud Number 14 of 2018 concerning the admission of new students at the TK, SD, SMP, SMA, SMK or 
other equivalent levels. As for the new academic year 2019/2020, this policy has been revised again in Permendikbud Number 51 of 2018. Permendikbud Number 51 of 2018 aims to provide solutions to the problems of equitable education in Indonesia. Equitable education is an issue of the education system that provides equal and comprehensive access to all citizens to obtain education. Because the zoning system prioritizes distance, it certainly results in a negative view of the community, especially parents of students. The negative view of parents, namely that efforts to get good UN scores are in vain, so that children cannot enter public schools according to their wishes and hopes. On the other hand, the zoning system is considered unfair because it only provides $5 \%$ of the pathway for achievement of the total number of students, while many of the prospective guardians want their children to go to schools that have adequate education standards and infrastructure even though constrained by remote domiciles. This then led to an initiation by the parents of students to flock before the admission of new students to move domicile near the school of choice. In addition, it was found that the parents of students had fake incapacity certificates and fake KK. This happens because parents do not hesitate to put their children on their sibling's family card in order to enter the school they want.

The meaning of zoning is basically a development of rayonization (Alfian, 2019; Perdana, 2019). If rayonization is an area division based on an agreement, then zoning emphasizes the division of the area according to its management objectives and functions. In the context of education, the zoning system leads to equal access and quality of education through education units in Indonesia. Research (Andina, 2017; Perdana, 2019) shows that the mechanism in PPDB raises various problems in its implementation. First, the socialization factor. The technical implementation of socialization and school capacity is inadequate and there are still disparities in quality between schools. Second, on the one hand the zoning system used in the admission of new students is aimed at facilitating access to schools. On the other hand, students who excel and do not have a tendency to possibly influence the achievement of students who are already good. Third, class standards are low. Based on preliminary observations of the zoning system in Pasuruan City through the Pasuruan City Education and Culture Office on June 17, 2020 (Ta'dimatul Fatma, 2020) it shows that; (a) the zoning system has been implemented in Pasuruan City, (b) there are written regulations regarding the implementation of zoning system policies in Pasuruan City, (c) there are technical guidelines regarding zoning system policies in Pasuruan City, (d) there is socialization regarding the requirements and flow of registration admission of new students (PPDB), (e) there is a schedule and time for registration, (f) there is a score for PPDB supporting values, (g) there is a school capacity, and (h) there is a division of zoning area designations. The data above shows that the readiness of implementing the zoning system related to increasing access and equitable quality of education is in accordance with the mandate of the 1945 Constitution to provide opportunities for every community to fulfill their basic rights to get education. 
Based on the above problems and the importance of examining the application of the zoning system, especially in Pasuruan City, this paper aims to explain the perceptions of parents of students on the application of the zoning system, expanding access and improving the quality of education in Pasuruan City at the time of the zoning system. In general, it provides a vehicle for comprehensive knowledge on the implementation of zoning system policies which incidentally involve districts / cities in Indonesia.

\section{METHOD}

The method used in this study is qualitative approach with field study method. The procedure of the field study are as follows : first, planning, the researcher prepares and selects the references and elaborates the research instruments. Second, the researcher decides the research location to get the access for observing and getting data. Third, the researcher starts to observe and have interview in research location. Fourth, the researcher chooses the social role. Fifth, the researcher gathers the data in research location.

This field study method is used to get data by obseving and interviewing the research subjects in this case the parents of students, then they are combined with some literatures to get theoritical subjects and some material concepts got from some research journal and some government information.

The subject of this research is eight parents from some senior high schools in Kota Pasuruan.the subjects of this research is widen because of the rules of Pasuruan Kota government of zoning system.Kota Pasuruan Zoning system are divided into one zone for some districts like Bugulkidul, Gadingrejo, Panggungrejo, Purworejo, rejoso, Kraton and Phjentrek for SMAN 1 Pasuruan, SMAN 2 Pasuruan, SMAN 3 Pasuruan and SMAN 4 Pasuruan. The data of observation and interview and some material concepts taken from some research journals and government data then anlyzed by the researcher to get good research results and discussion. Some explanation will be emphasized in this articles from some references researcher has. (A. Muri Yusuf, 2016; Perdana, 2019).

\section{RESULTS AND DISCUSSION}

Parents' Perceptions of the Zoning System in Pasuruan City.

The following is a diagram of parents' perceptions of the zoning system in Pasuruan City. 


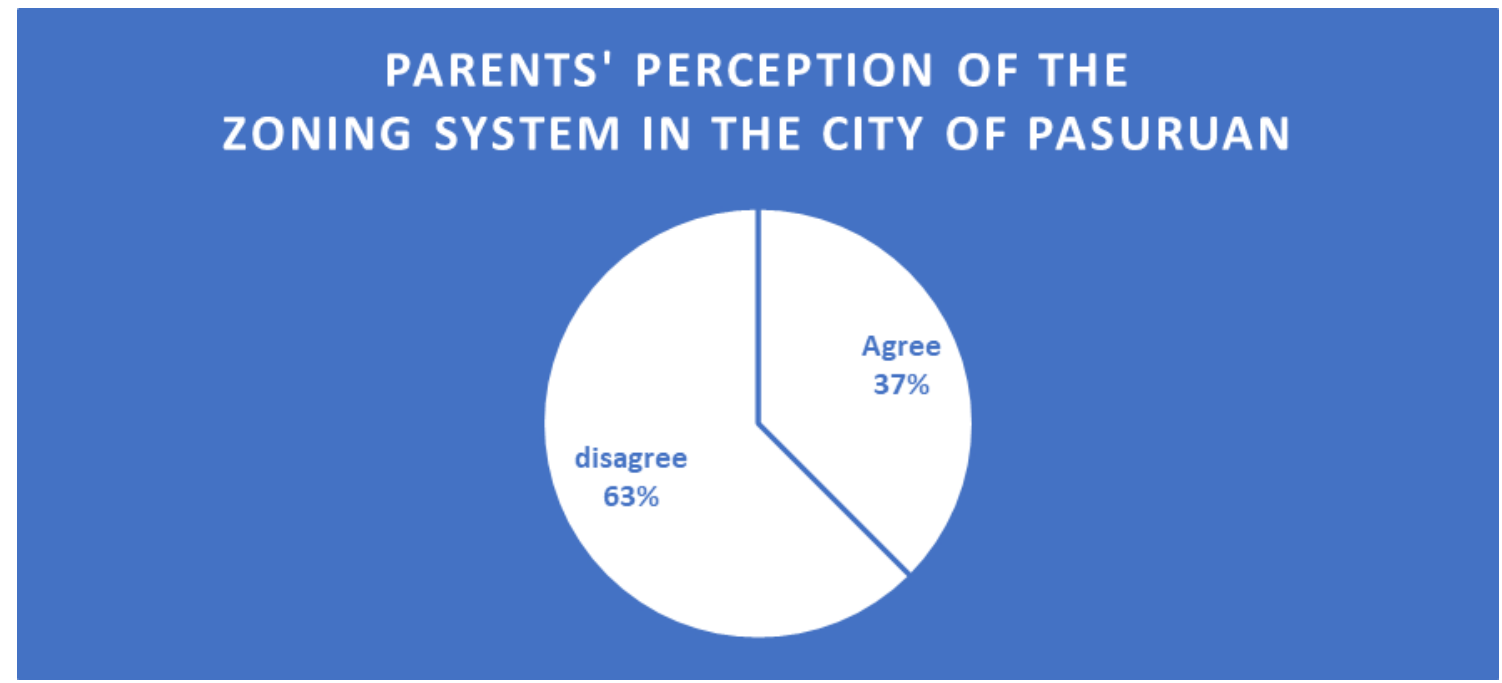

From the results of interviews with 8 parents of students, it was found that $37 \%$ agreed with the zoning system while $63 \%$ did not agree with the zoning system. Parents' who disagree are (63\%), it was more on the lack of understanding of technology and information as well as lack of technical socialization of zoning implementation. The technology and information were related to registration procedures, and requirements to internet connection problems. This was of course a problem for parents that were not good in technology, so that they did not agree with the zoning system.

In contrast to the perception of parents who agree (37\%) to the zoning system, most of them felt helped because of their busy time of working and their limited time to directly accompanying their children to come to registration place. Technology and information problems related to online registration procedures were considered to be the best solution and an effective choice because it is easier, save time, and save energy.

Parents' perceptions of the zoning system can be studied from four perspectives, they were socialization, technical constraints, availability of student quotas, and minimizing disparities between schools. First, socialization. A Not optimal socialization of the zoning system, of course, has an impact on negative perceptions (disagree) of parents of students on the zoning system. Socialization could be carried out to parents directly or through branch offices, sub-district heads, village heads, school principals and community leaders. The findings of field data related to the zoning system encourage parents to manipulate house distance data, they tried to sell and buy popular school chairs, and use KIP (Smart Indonesia Card) and KIS (Health Indonesia Card) ownership to be accepted by schools (Andina, 2017; Daryono, 2020; Dewi et al., 2019). Second, technical constraints. Technical constraints related to technology and information that need to be mastered by parents of students. Technical problems, especially at the online selection stage, were caused by inadequate servers resulting in disruption during the selection process. On the other hand, there were limited human resources who were assigned to handle technical problems. Third, the availability of students' quota. The problem that occurs in the field is the unbalanced quota of students. 
The imbalance between the quota and registrants caused the competition for seats in public schools to become more crowded and not all prospective students are accommodated in schools that are close to their houses. Fourth, minimizing disparities between schools. Facts in the field, disparities between schools was the task of the city / district, provincial and Ministry of Education and Culture education offices that must be addressed so that all schools are proper. In addition to the problems of infrastructure, school human resources, including school principals, teaching staff and education personnel, were also required to create an adequate environment for learning.

\section{Expanding Access and Improving the Quality of Education}

The following shows the reference data for the Pasuruan City education unit.

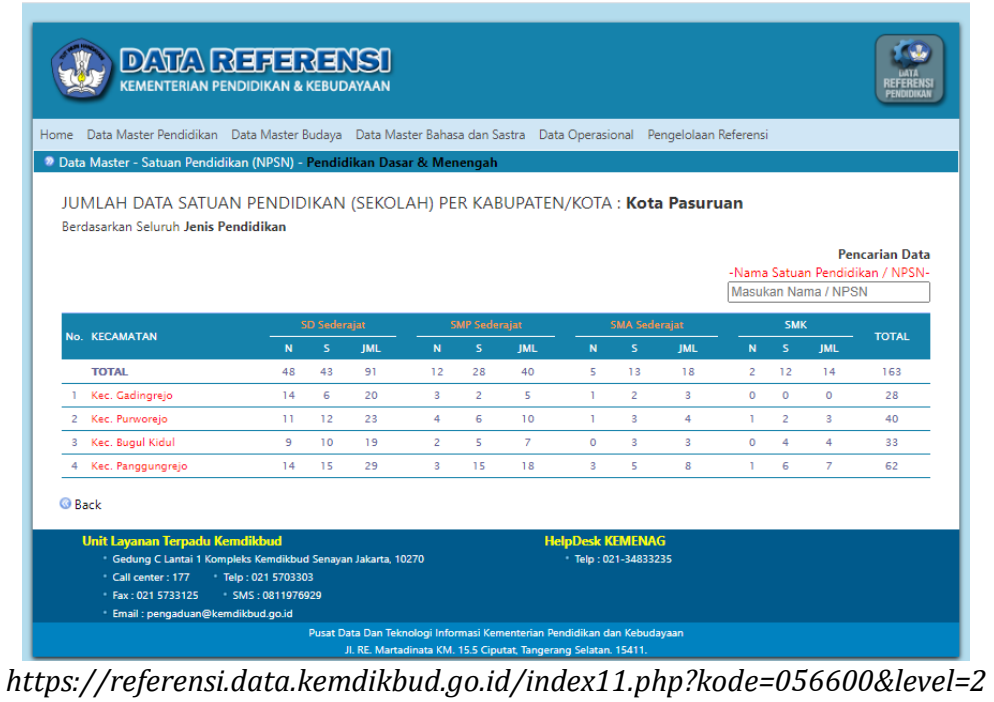

Zoning system has both advantages and disadvantages. At least the zoning system will provide broad access and improve the quality of education even though there are deficiencies on many sides. The zoning system will provide advantages for students, prospective who live near to schools. Even though they excel, prospective students can continue their education at the school closest to their domicile. On the other hand, the zoning system encourages high-achieving students to register at the closest school, even though it is not the school with the best quality. So that even distribution of the quality of education can slowly be realized.

The context of expanding access and improving the quality of education in the zoning system in Kota Pasuruan through the process of admitting new students was carried out systematically. The systemic PPDB (new students' acceptance) implementation process was a procedural and structured implementation based on the PPDB system. Analysis of school needs for students was used as a reference in each sub-district area in determining zoning areas by referring to the 2020 Mayor Regulation concerning PPDB (new students' acceptance)technical guidelines. The following were a need analysis for the implementation of the zoning system. First, parents' understanding of the zoning policy in Kota Pasuruan was an important aspect for the implementation besides the distance from home to school. This was done to equalize the quality of education so that there were no more favorite school labels. This explanation contradicts Permendikbud No. 
$17 / 2017$ article 2 that the admission of new students aimed to ensure that the admission of new students runs objectively, accountably, transparently and without discrimination so as to encourage the quality of education services. Second, parents' understanding of the zoning system was still limited. The majority of parents were still unfamiliar with the zoning system, especially the procedures and techniques for implementing the zoning system. It was found that less optimal socialization regarding the zoning system was found. The perceptions of some parents of students are only based on distance. Parents 'perceptions were more on the distance between the house to the school, not on the substance of the zoning system, like the zoning route, the path of achievement, the path of affirmation and the transfer of parents' tasks. The zoning policy by considering the real needs analysis was good by considering the expansion of access and improving the quality of education, however the less than optimal information about the zoning system actually creates negative perceptions (disagree) regarding the zoning program.

The impact of this zoning system policy was divided into 4 systems (Asri, 2019; Daryono, 2020; Jenderal \& Tinggi, 2014; Perdana, 2019; Syamsul, 2020; Ta'dimatul Fatma, 2020) they were the zone between the distance from the house to the school, the second zone for children who excel in both academic and non-academic fields, the third zone is for students who are unable (affirmation), and the fourth is for students whose parents have job transfer to the area (transfer of work of parents ). By this division, parents were easier to control and monitor their children both at home and at school.

This zoning policy indirectly trained students to compete, be independent and increase their achievement to be able to enter the desired school. Students were passionate about developing their potential and talent interests. There were zoning policies aimed at students who excel both academically and nonacademically. This route eased students to come to the school they want, even though the capacity for this route was only $30 \%$ of the $100 \%$ quota needed. This path only covered the championship charter.

The findings of the field data, the researcher found several positive impacts and negative impacts, they were (a) the positive impact was the implementation of zoning policies carried out by the government for the process of admitting new students in Kota Pasuruan. The following was the positive impact of implementing the zoning system, as followed (a) this regulation made by the government based on the distance between the house and the school. This was in accordance with the regulations made by the government in Permendikbud number 44 of 2019 article 11 paragraph (2) that the education unit accepts prospective students based on domicile in the zone $50 \%$ of the total ceiling, (b) Parents can supervise children's relationships by easy, both at school and in the home environment. With this policy, parents can easily supervise their children. Starting from association, and whatever happens to students, (c) in this policy there is also an achievement path made by the government. This pathway will make it easier for students to enter the school they want by attaching the achievement chart that the students have. Although only $30 \%$ but very helpful for students. This was in line with Permendikbud Number 44 of 2019 article 15 paragraph (5) that the track of achievement who lives outside the school radius is at most $30 \%$ of the total ceiling. 
Pasuruan City has its own criteria, the minimum charter used is the city / regency level, a certificate of competency test for reading the Qur'an, with the minimum criteria being good, and a certificate of achievement by memorizing the Al-Qur'an at least 1 Juz. This has been determined by Kota Pasuruan Government (Ta'dimatul Fatma, 2020). Next was the negative impact of the zoning system policy for the admission of new students. This school zoning policy has many negative impacts according to the perceptions of parents of students. Because with this policy parents cannot choose schools. And it is considered to undermine human rights. They must comply with the rules made by the government. Based on the results of the interview the negative impact of zoning, namely teacher pressure and its impact on students, this has a consequence that schools must prioritize student access to schools based on domicile, not on values that have been the conventional mechanism for admitting new students.

The direct impact was a decrease in the value input obtained by the school and this is stated to reduce the ranking of school achievement. This applied to favorite schools. The negative impact felt by the parents of students is quite unfair because prior to this policy the schools had their own image and achievements that were built over several decades but were threatened with disappearing in an instant (Daryono, 2020; Firmansyah, 2018; Imam Nur Aziz, 2019; Ta'dimatul Fatma, 2020). The implementation of new student policies with zoning policies made things even more complicated. This was because there were various traits / abilities of students, the gathering of students who have different abilities and traits in one class makes their interest in learning decrease. The role of the teacher here was required to be more active in dealing with these students. The most negative impact of the zoning policy was this zoning was considered to reduce the rights of students. With this policy, students couldnot go to the school they want because of the limited class quota by the government. Students assumde that no matter how high their grades were, they will not be able to choose a school. In fact, this policy has no impact on the parents, it's just had a huge impact on students.

\section{CONCLUSION}

Parents 'perceptions of the zoning system policy can be seen from their parents' understanding of zoning policies in Pasuruan City. From the results of the study, most of the parents of students assumed that the zoning system policy was a process of admitting new students based on distance, namely the distance between the house to the school. The impact of this zoning system policy has an impact on parents. The positive impact is that parents of students do not bother thinking about money for children's transportation costs, parents of students are easier to supervise the association of children at school and in the home environment, the zoning system can indirectly train the independent nature of children for competition so that they can enter school What is desired, the school zoning system policy with the existence of an achievement pathway or zone 3 will make it easier for students to be accepted into the school by attaching achievements or proof of the student's charter. Meanwhile, the negative impact is that children cannot choose the school they want. The extent of access and improving the quality of education is not in accordance with what the government wants, the response of 
parents of students regarding the zoning policy in the admission of new students in Pasuruan City is deemed unfair or dwarfs the rights of students because it only focuses on the distance between home and school while the value is not be a consideration for admission to the school. The policy needs to be reviewed because there is no dissemination in circulation, even though previously this PPDB or zoning policy was implemented 3 years ago. Students have the right to determine the school according to the wishes of these students so that it does not cause dwarfing their rights.

\section{REFERENCES}

A. Muri Yusuf. (2016). Metode Penelitian Kuantitatif, Kualitatif \& Penelitian Gabungan. PT. Fajar Interpratama Mandiri. Yusuf, A. M. (2016). Metode Penelitian Kuantitatif, Kualitatif \& Penelitian Gabungan. Prenada Media.

Alfian, M. A. (2019). Politik Zonasi Dalam Praktik Pendidikan Di Indonesia * Suatu Telaah Awal Zoning Politics In Educational Practices In Indonesia ${ }^{*} A$ Preliminary Study. 1(2), 118-134. https://journal.uinsgd.ac.id/index.php/politicon/article/view/6363

Andina, E. (2017). SISTEM ZONASI DAN DAMPAK PSIKOSOSIAL BAGI PESERTA DIDIK. Majalah Info Kesejahteraan Sosial, 9-12. https://scholar.google.co.id/scholar?hl=id\&as_sdt=0\%2C5\&q=andina+2017+ zonasi\&btnG=

Asri, M. F. (2019). Pengaruh Sistem Zonasi Terhadap Kualitas Pendidikan Di Indonesia (pp. 1-9). https://doi.org/10.31219/osf.io/erbd4

Daryono. (2020). Menuju Manajemen berbasis Sekolah (M. Z. A. A. I. S.M (ed.); 1st ed.). Lembaga Academic \& Research Institute. https://books.google.co.id/books?id=qkDZDwAAQBAJ\&lpg=PP1\&ots=PiqiVYx ooR\&lr\&hl=id\&pg=PR2\#v=onepage \&q\&f=false

Dewi, I. A. P. R., Suharsono, N., \& Meitriana, M. A. (2019). Persepsi warga sekolah dan orang tua siswa terhadap sistem zonasi. Jurnal Pendidikan Ekonomi, 11(2), 552-561.

https://ejournal.undiksha.ac.id/index.php/JJPE/article/view/21569

Firmansyah, M. B. (2018). MODEL PEMBELAJARAN DISKUSI BERBASIS PERILAKU BERLITERASI UNTUK KETERAMPILAN BERBICARA_BAYU_sept_2017. Edukasi Dan Sosial, 8(September 2017), 119-125. https://doi.org/10.31227/osf.io/ebx9j

Imam Nur Aziz. (2019). PEMERATAAN AKSES PENDIDIKAN BAGI MASYARAKAT INDONESIA. Researchgate, 12(3),

14. https://scholar.google.co.id/scholar?start=10\&q=Perluasan+Akses+Dan+Peni ngkatan+Mutu+Pendidikan+dalam+sistem+zonasi\&hl=id\&as_sdt=0,5\&scioq= SISTEM+ZONASI+DAN+DAMPAK+PSIKOSOSIAL+BAGI+PESERTA+DIDIK

Jenderal, D., \& Tinggi, P. (2014). Kementerian pendidikan dan kebudayaan IPTEKS (2019, Vol. 57946100, Issue 021). http://kebudayaan.kemdikbud.go.id/muspres/wpcontent/uploads/sites/38/2019/11/kumpulan-Kilasan-2019.pdf

Perdana, N. S. (2019). Implementasi ppdb zonasi dalam upaya pemerataan akses dan mutu pendidikan. 3(April), 78-92. 
http://lonsuit.unismuhluwuk.ac.id/index.php/glasser/article/view/186

Syamsul, R. L. (2020). Analisis implementasi kebijakan zonasi dalam pemerataan $\begin{array}{lll}\text { pendidikan. } & \text { Mappesona, } & \end{array}$ https://jurnal.uns.ac.id/candi/article/viewFile/44799/28330

Ta'dimatul Fatma, A. M. D. (2020). PERSEPSI ORANG TUA TERHADAP KEBIJAKAN SISTEM ZONASI DALAM PENERIMAAN PESERTA DIDIK BARU DI KOTA PASURUAN (p. 9).

A. Muri Yusuf. (2016). Metode Penelitian Kuantitatif, Kualitatif \& Penelitian Gabungan. PT. Fajar Interpratama Mandiri. Yusuf, A. M. (2016). Metode Penelitian Kuantitatif, Kualitatif \& Penelitian Gabungan. Prenada Media.

Alfian, M. A. (2019). Politik Zonasi Dalam Praktik Pendidikan Di Indonesia * Suatu Telaah Awal Zoning Politics In Educational Practices In Indonesia * A Preliminary Study. 1(2), 118-134. https://journal.uinsgd.ac.id/index.php/politicon/article/view/6363

Andina, E. (2017). SISTEM ZONASI DAN DAMPAK PSIKOSOSIAL BAGI PESERTA DIDIK. Majalah Info Kesejahteraan Sosial, 9-12. https://scholar.google.co.id/scholar?hl=id\&as_sdt=0\%2C5\&q=andina+2017+ zonasi\&btnG=

Asri, M. F. (2019). Pengaruh Sistem Zonasi Terhadap Kualitas Pendidikan Di Indonesia (pp. 1-9). https://doi.org/10.31219/osf.io/erbd4

Daryono. (2020). Menuju Manajemen berbasis Sekolah (M. Z. A. A. I. S.M (ed.); 1st ed.). Lembaga Academic \& Research Institute. https://books.google.co.id/books?id=qkDZDwAAQBAJ\&lpg=PP1\&ots=PiqiVYx ooR\&lr\&hl=id\&pg=PR2\#v=onepage \&q\&f=false

Dewi, I. A. P. R., Suharsono, N., \& Meitriana, M. A. (2019). Persepsi warga sekolah dan orang tua siswa terhadap sistem zonasi. Jurnal Pendidikan Ekonomi, 11(2), 552-561.

https://ejournal.undiksha.ac.id/index.php/JJPE/article/view/21569

Firmansyah, M. B. (2018). MODEL PEMBELAJARAN DISKUSI BERBASIS PERILAKU BERLITERASI UNTUK KETERAMPILAN BERBICARA_BAYU_sept_2017. Edukasi Dan Sosial, $\quad$ 8(September 2017), $119-125$. https://doi.org/10.31227/osf.io/ebx9j

Imam Nur Aziz. (2019). PEMERATAAN AKSES PENDIDIKAN BAGI MASYARAKAT $\begin{array}{lll}\text { INDONESIA. } & \text { Researchgate, } & 12(3),\end{array}$ https://scholar.google.co.id/scholar?start=10\&q=Perluasan+Akses+Dan+Peni ngkatan+Mutu+Pendidikan+dalam+sistem+zonasi\&hl=id\&as_sdt=0,5\&scioq= SISTEM+ZONASI+DAN+DAMPAK+PSIKOSOSIAL+BAGI+PESERTA+DIDIK

Jenderal, D., \& Tinggi, P. (2014). Kementerian pendidikan dan kebudayaan IPTEKS (2019, Vol. 57946100, Issue 021). http://kebudayaan.kemdikbud.go.id/muspres/wpcontent/uploads/sites/38/2019/11/kumpulan-Kilasan-2019.pdf

Perdana, N. S. (2019). Implementasi ppdb zonasi dalam upaya pemerataan akses dan mutu pendidikan. 3(April), 78-92. http://lonsuit.unismuhluwuk.ac.id/index.php/glasser/article/view/186

Syamsul, R. L. (2020). Analisis implementasi kebijakan zonasi dalam pemerataan $\begin{array}{lll}\text { pendidikan. } & \text { Mappesona, } & 1\end{array}$ https://jurnal.uns.ac.id/candi/article/viewFile/44799/28330 
Volume 4 Number 3 March 2021

Ta'dimatul Fatma, A. M. D. (2020). PERSEPSI ORANG TUA TERHADAP KEBIJAKAN SISTEM ZONASI DALAM PENERIMAAN PESERTA DIDIK BARU DI KOTA PASURUAN (p. 9). 